\title{
Pengaruh Fenomena IOD (Indian Ocean Dipole) Terhadap Sebaran Temperatur dan Salinitas di Perairan Barat Sumatera
}

\author{
Fannia Wahyu Ramadhanty ${ }^{1 *}$, Muslim $^{1}$, Kunarso $^{1}$, Baskoro Rochaddi $^{1}$ \\ dan Dwi Haryo Ismunarti ${ }^{1}$
}

\author{
${ }^{1}$ Departemen Oseanografi, Fakultas Perikanan dan Ilmu Kelautan, Universitas Diponegoro \\ Jl. Prof. H. Soedarto, S.H, Tembalang Semarang. 50275 Telp/fax (024)7474698 \\ Email : fanniawr1998@gmail.com
}

\begin{abstract}
Abstrak
Perairan Barat Sumatera dan sekitarnya mendapatkan pengaruh signifikan dari massa air Samudera Hindia, massa air tersebut memberikan perubahan terhadap kondisi oseanografi seperti temperatur dan salinitas. Fenomena IOD (Indian Ocean Dipole) merupakan fenomena antara lautan-atmosfer yang terjadi di daerah ekuator Samudera Hindia, yang memberikan dampak kekeringan ataupun peningkatan intensitas curah hujan. Penelitian ini bertujuan untuk menganalisis pengaruh fenomena IOD terhadap perubahan nilai temperatur dan salinitas, secara vetikal maupun horizontal yang dapat digunakan untuk mengidentifikasikan karakteristik massa air dengan melakukan perhitungan diagram T-S. Penelitian ini menggunakan metode kuantitatif dan deskriptif. Data temperatur, salinitas, dan kedalaman didapat dari instrumen Argo Float tahun 2014 - 2020. Kemudian untuk mendapatkan sebaran vertikal, horizontal, dan Diagram T-S menggunakan software Ocean Data View (ODV). Beradasarkan hasil olahan tersebut didapatkan sebaran temperatur secara vertikal menunjukkan temperatur di lapisan Mixed Layer (0-25 m) yaitu $27,86-31,4^{\circ} \mathrm{C}$, lapisan termoklin $(26-180 \mathrm{~m})$ yaitu $14,78-26,05^{\circ} \mathrm{C}$, dan lapisan dalam (181-2000 m) 2,63-13,03 ${ }^{\circ}$. Sebaran salinitas secara verikal di lapisan Mixed Layer (0-24 m) yaitu 32,5-33,62 psu, lapisan haloklin (25-123 m) 33,7-34,63 psu, lapisan dalam (125-2000 m) 34,8-35,2 psu. Sebaran temperatur dan salinitas secara horizontal dipengaruhi oleh musim, dimana temperatur permukaan tertinggi $\left(31,39^{\circ} \mathrm{C}\right)$ terjadi pada musim Peralihan I, sedangkan salinitas permukaan tertinggi $(35,6 \mathrm{psu})$ terjadi pada Peralihan II. Berdasarkan Diagram T-S massa air yang teridentifikasi pada Perairan Barat Sumatera yaitu massa air BBW (Bengal Bay Water), SLW (Subtropical Lower Water), SICW (South Indian Central Water), IEW (Indian Equatorial Water), NSM (Northern Salinity Minimum), dan ASW (Arabian Sea Water). Pada saat IOD positif tertinggi (2019) mengakibatkan penurunan temperatur dan kenaikan rerata salinitas, ketika IOD negatif (2016) mengakibatkan kenaikan temperatur dan penurunan rerata salinitas.
\end{abstract}

Kata kunci : Barat Sumatera, IOD, temperatur, salinitas, massa air

\begin{abstract}
The western part of Sumatera sea and its surrounding significantly influence of the water mass coming from the Indian Ocean, which give changes to oceanographic conditions such as temperature and salinity. Phenomena IOD (Indian Ocean Dipole) is phenomenon between the ocean and atmosphere that occurs in the equatorial area of the Indian Ocean, which results in dorught or increased rainfall intensity. This research aims to analyze the impact of phenomena IOD on changes in temperature and salinity values, both vertical and horizontal which can be used to identify the characteristic of water mass by calculating the T-S diagram. The method used by quantitative and then describing. The data used to analyze is temperature, salinity, and data sets from Argo Float instruments 2014 to 2020. Then to get the vertical, horizontal, and T-S diagrams using software Ocean Data View (ODV). The results of data analysis showed that the temperature distribution vertically shows the temperature in the Mixed Layer $(0-25 \mathrm{~m})$ is $27,86-31,4^{\circ} \mathrm{C}$, the thermocline layer $(26-180 \mathrm{~m})$ which is $14,78-26,05^{\circ} \mathrm{C}$, and deep layer (181-2000 m) 2,63-13,03 ${ }^{\circ} \mathrm{C}$. The vertical distribution of salinity in the Mixed Layer $(0-24 \mathrm{~m})$ is 32,5-33,62 psu, the halocline layer (25-123 m) 33,7-34,63 psu, the inner layer (125-2000 m) 34,8-35,2 psu. The distribution of temperature and salinity horizontally is influenced by seasons, where the highest sea surface temperature (SST) is $31,39^{\circ} \mathrm{C}$ occurs in the first transitional season, while the highest surface
\end{abstract}


salinity (35,6 psu) occurs in second transitional season. Based on the T-S diagram the water masses identified in the West Sumatran sea region is Bengal Bay Water (BBW), Subtropical Lower Water (SLW), South Indian Central Water (SICW), Indian Equatorial Water (IEW), Northern Salinity Minimum (NSM), dan Arabian Sea Water (ASW). The highest positive IOD (2019) resulted in a decrease in temperature and an increase in salinity, when a negative IOD (2016) resulted in an increase in temperature and a decrease in mean salinity.

Keywords : West Sumatera, temperature, salinity, water mass, IOD

\section{PENDAHULUAN}

Samudera Hindia merupakan salah satu perairan terbesar yang memiliki pengaruh langsung terhadap perairan Indonesia, khusunya Perairan Barat Sumatera. Pengaruh tersebut menjadikan Perairan Barat Sumatera memiliki sifat perairan yang unik dan kompleks, karena Samudera Hindia membawa massa air dari beberapa perairan sekitar seperti Laut Arab, Laut Persia, Laut Andaman, dan Teluk Bengal, dengan kata lain wilayah perairan ini memiliki masukan dari beberapa muara sungai besar yang membawa nilai temperatur dan salinitas yang beragam (Wyrtki, 1961).

Samudera Hindia memiliki fenomena antar tahunan yang dikenal dengan IOD (Indian Ocean Dipole), yang memberikan dampak kekeringan ataupun peningkatan intensitas curah hujan yang mempengaruhi nilai temperatur dan salinitas (Saji et al., 1999). Salinitas dan temperatur merupakan parameter yang penting, karena parameter tersebut dapat menjelaskan kondisi suatu perairan. Sebaran secara vertikal terhadap temperatur dan salinitas dapat menunjukkan lapisan kolom perairan yang membagi beberapa lapisan, serta memiliki variabilitas berbeda di setiap lapisan. Sedangkan sebaran secara horizontal, akan menunjukkan profil temperatur dan salinitas pada suatu perairan yang berkaitan dengan siklus perubahan musim. Hal tersebut yang menjadikan analisis sebaran temperatur dan salinitas secara vertikal dan horizontal pada Perairan Barat Sumatera perlu dilakukan.

Diagram T-S menjadi alat deskriptif dalam penentuan jenis massa air pada Perairan Barat Sumatera. Seperti halnya yang telah dilakukan oleh Emery (2003) dan Wyrtki (1961) dalam mengidentifikasikan massa air. Diagram T-S dapat menunjukkan bagaimana hubungan kepadatan nilai temperatur dan salinitas yang diamati, serta menunjukkan pencampuran dari beberapa massa air yang berbeda. Menurut Emery (2003) Diagram T-S pada Samudera Hindia memiliki salinitas yang tinggi, akibat masukan salinitas dari perairan sekitar. Hal tersebut menjadikan identifikasi karakteristik massa air pada Perairan Barat Sumatera menarik untuk dikaji.

Fenomena IOD serta adanya pengaruh masukan dari perairan sekitar Samudera Hindia menjadi permasalahan dalam penelitian ini, sehingga perlu dianalisa bagaimana pengaruh IOD terhadap sebaran temperatur salinitas yang spesifik, serta massa air pada tahun 2014-2020 di Perairan Barat Sumatera.

\section{MATERI DAN METODE}

Materi penelitian terbagi menjadi dua yaitu data utama dan data penunjang. Data utama yang digunakan adalah data Argo Float pengukuran temperatur, salinitas, dan kedalaman yang berada disekitar perairan barat Sumatera pada 2014 - 2020, data tersebut merupakan data pengukuran secara langsung di lapangan menggunakan instrumen. Sedangkan data penunjang atau data sekunder yang digunakan yaitu Index IOD (Indian Ocean Dipole) berupa data DMI (Dipole Mode Index) untuk analisis hubungan tahun kejadian kondisi Dipole Mode pada periode tahun 2014 - 2019. Data pendukung lainya adalah Peta Rupa Bumi Indonesia.

Penelitian ini dilaksanakan pada bulan Agustus 2014 sampai Januari 2020. Wilayah kajian penelitian berada di Perairan Barat Sumatera dengan batasan wilayah berkoordinat $73^{\circ} \mathrm{BT}-102 \mathrm{BT}$ dan 6 LU-6 LS (Gambar 1). 


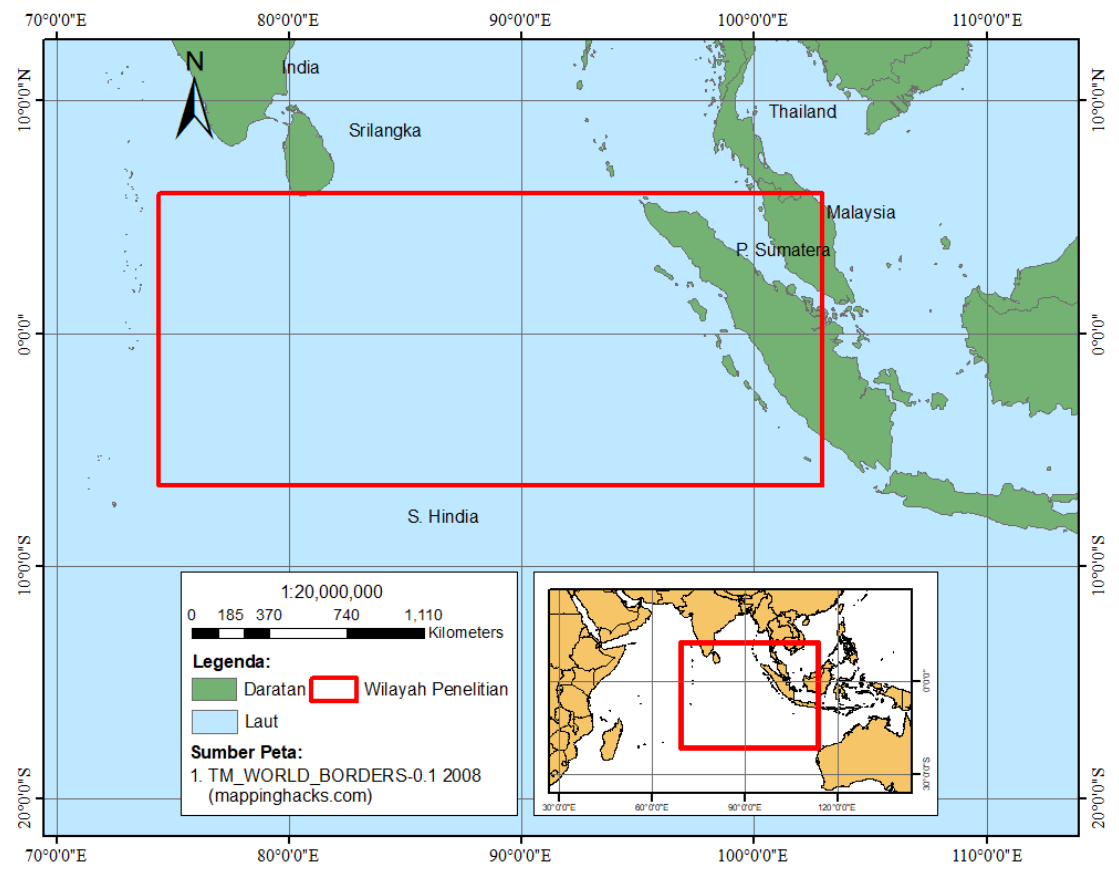

Gambar 1. Peta Lokasi Penelitian

Penelitian ini menggunakan metode kuantitatif. Metode kuantitatif menurut Sugiyono (2009) merupakan metode yang telah memenuhi kaidah-kaidah ilmiah yang konkret, obyektif, terukur dan sistematis serta memberikan data penelitian berupa angka-angka dan menganalisanya. Hasil pengolahan data secara kuantitatif digunakan untuk mendiskripsikan bagaimana kondisi karakteristik massa air di Perairan Barat Sumatera serta bagaimana kondisi temperatur dan salinitas terhadap fenomena antartahunan yaitu IOD (Indian Ocean Dipole).

Pengambilan data oseanografi (temperatur dan salinitas) dilakukan dengan instrument Argo Float model APEX (Float). CTD secara otomatis bergerak naik turun dalam selang waktu setiap 10 hari sekali (Pranowo et al., 2003). Data oseanografi yang dikumpulkan untuk penelitian ini terdiri dari data temperatur, salinitas, dan kedalaman. Data Argo Float tersebut dapat diperoleh dari http://www.jcommops.org. Format data yang digunakan oleh Argo float adalah NetCDF (Network Common Data Form). Data tersebut di import ke Ocean Data View (ODV) menjadi file tipe *txt. Pengolahan data pada aplikasi ODV dilakukan untuk menghasilkan sebaran vertikal dan horizontal temperatur serta salinitas, dan diagram T-S.

Analisis sebaran vertikal temperatur dan salinitas ditampilkan dalam grafik menegak, dengan kedalaman 0 hingga $2000 \mathrm{~m}$, serta akan menjelaskan kondisi pada lapisan yaitu: tercampur, termoklin/haloklin, dan dalam. Pembagian 3 lapisan ditentukan dengan menghitung gradien temperatur dan salinitas. Sedangkan berdasarkan pola sebaran secara horizontal, dilakukan analisis time series yaitu pada Agustus 2014 - Januari 2020 dengan kedalaman 0-500 meter. Berdasarkan pengolahan data maka dapat diketahui bagaimana variasi nilai temperatur dan salinitas dengan bertambahnya kedalaman dan dikaitkannya dengan siklus perubahan musim yang terjadi pada lokasi penelitian yaitu: Musim Barat, Musim Timur, Peralihan I dan II.

Massa air pada penelitian ini secara kualitatif diidentifikasikan dengan diagram T-S yang menunjukkan hubungan potensial temperatur dan salinitas. Berdasarkan profil diagram T-S dapat mengidentifikasikan massa air yang terdapat di Perairan Barat Sumatera. Pada penelitian ini jenis massa air diidentifikasikan berdasarkan Emery (2003) seperti pada Tabel 1 dan Wyrtki (1961) pada Tabel 2. 
Tabel 1. Klasifikasi Massa Air Samudera Hindia menurut Emery (2003)

\begin{tabular}{clcc}
\hline Lapisan & \multicolumn{1}{c}{ Massa Air } & $\begin{array}{c}\text { Temperatur } \\
\left({ }^{\mathbf{C}} \mathbf{C}\right)\end{array}$ & $\begin{array}{c}\text { Salinitas } \\
(\mathbf{p s u})\end{array}$ \\
\hline Perairan Atas (Upper Water) & Bengal Bay Water (BBW) & $25-29$ & $28-35$ \\
$0-500 \mathrm{~m}$ & Arabian Sea Water (ASW) & $24-30$ & $35,5-36,8$ \\
& Indian Equatorial Water (IEW) & $8-23$ & $34,6-35$ \\
& Indonesian Upper Water (IUW) & $8-23$ & $34,4-35$ \\
& South Indian Central Water (SICW) & $8-25$ & $34,6-35,8$ \\
\hline
\end{tabular}

Tabel 2. Klasifikasi Massa Air Samudera Hindia menurut Wyrtki (1961)

\begin{tabular}{lcc}
\hline \multicolumn{1}{c}{ Massa Air } & $\begin{array}{c}\text { Temperatur } \\
\left(\mathbf{}^{\mathbf{C}}\right)\end{array}$ & $\begin{array}{c}\text { Salinitas } \\
(\mathbf{p s u})\end{array}$ \\
\hline Subtropical Lower Water & $16-27$ & $34,6-36$ \\
Northern Salinity Minimum & $16-19$ & $34,8-35$ \\
Southern Salinity Minimum & $12-17$ & $34,5-34,8$ \\
Upper Oxygen Minimum & $12-16$ & $34,8-35,1$ \\
Persian Gulf Water & $8-14$ & $34,6-35,1$ \\
& $11-13$ & $34,9-35,1$ \\
Lower Oxygen Maximum & $8-11$ & $34,7-35,1$ \\
Red Sea Water & $7-9$ & $>34,8$ \\
& $6-10$ & $34,6-35$ \\
Banda Sea Water & $4,5-6$ & $34,5-34,9$ \\
\hline
\end{tabular}

Data variabilitas iklim IOD yang digunakan yaitu berupa nilai DMI yang merupakan indeks dari perbedaan anomali suhu permukaan laut di Samudera Hindia Barat dan Samudera Hindia Timur dalam bentuk indeks bulanan selama 5 tahun dari 2014 - 2019 yang dapat diunduh dari https://stateoftheocean.osmc.noaa.gov/sur/ind/dmi.php. Data yang digunakan merupakan data analisis Reynolds Olv2 SST weekly (mingguan) yang tersedia dari tahun 1982-2019 kemudian diolah menjadi data bulanan. Perhitungan DMI dilakukan oleh JAMSTEC dengan menggunakan metode rekonstruksi SPL IGOS. Indeks IOD (Indian Ocean Dipole) atau indeks DM (Dipole Mode) yang didefinisikan sebagai beda anomali temperatur permukaan laut Samudera Hindia bagian Timur dan Barat. Identifikasi tahun kejadian DM positif, negatif, dan netral dilakukan dengan ketentuan sesuai dengan pernyataan Adiwira et al., (2018) seperti berikut:

Tabel 3. Klasifikasi Dipole Mode Indeks

\begin{tabular}{ccc}
\hline Nomor & Nilai DMI & Keterangan \\
\hline 1 & DMI $>0,48^{\circ} \mathrm{C}$ & DM Positif \\
2 & $-0,48{ }^{\circ} \mathrm{C} \leq \mathrm{DMI} \leq 0,48{ }^{\circ} \mathrm{C}$ & DM Netral \\
3 & $\mathrm{DMI}<0,48^{\circ} \mathrm{C}$ & DM Negatif \\
\hline
\end{tabular}




\section{HASIL DAN PEMBAHASAN}

\section{Temperatur}

Pengolahan data temperatur menghasilkan sebaran vertikal termperatur yang disajikan pada Gambar 2, tampak penampang temperatur secara vertikal menunjukkan bahwa nilai temperatur pada permukaan Perairan Barat Sumatera berkisar $27-31,39^{\circ} \mathrm{C}$. Temperatur air berubah seiringnya bertambah kedalaman semakin dalam nilainya semakin kecil atau semakin dingin.

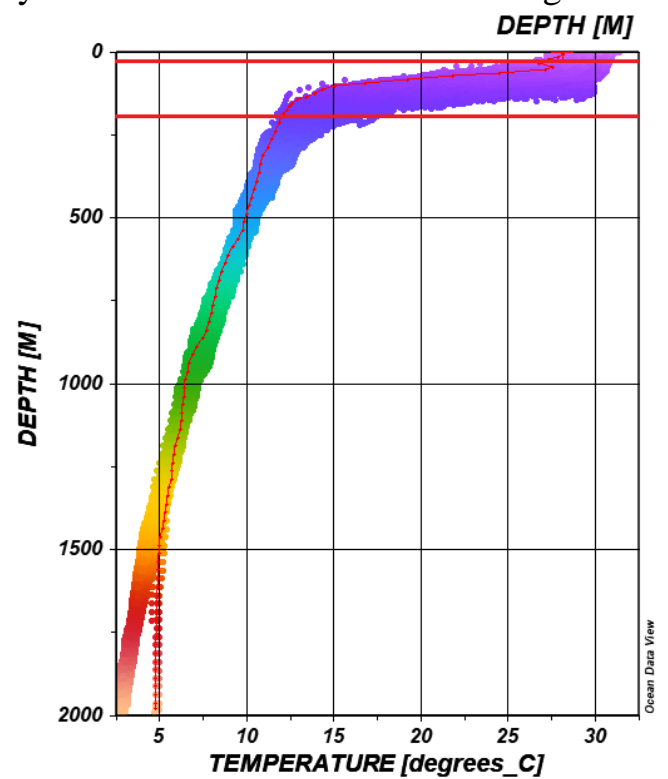

(a)

(b)

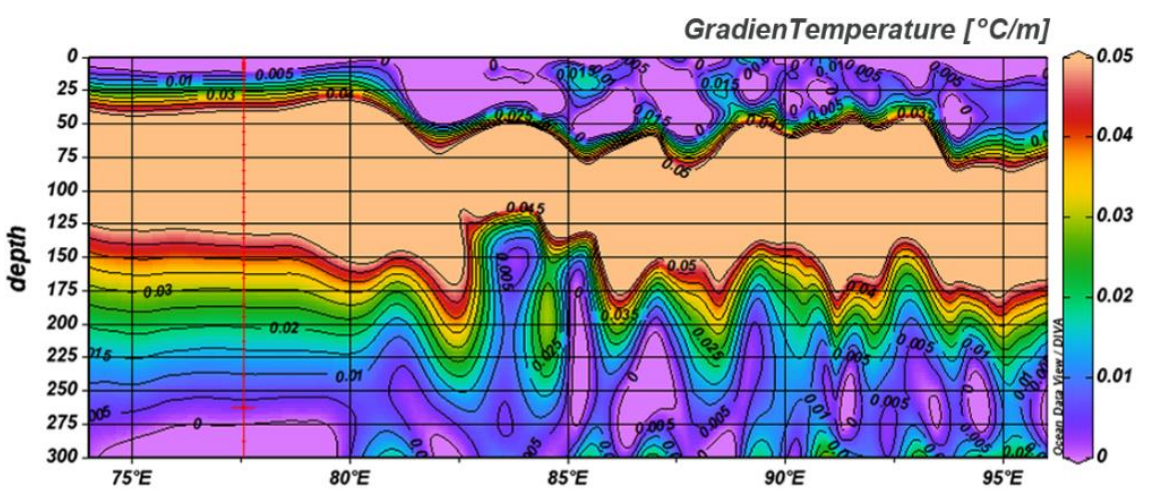

Gambar 2. (a)Sebaran Vertikal Temperatur, (b)Gradien Temperatur.

Sebaran temperatur secara vertikal pada Perairan Barat Sumatera terbagi dalam tiga lapisan utama, yaitu lapisan tercampur (mixed layer), lapisan termoklin (thermocline layer), dan lapisan dalam (deep layer). Gambar 2(a) menunjukan lapisan mixed layer berada pada kedalaman 0-25 meter, yang memiliki nilai temperatur $27,86-31,4^{\circ} \mathrm{C}$. Lapisan berikutnya, yaitu lapisan termoklin yang memiliki kedalaman 26-180 meter dengan temperatur $14,78-26,05^{\circ} \mathrm{C}$, dan gradien temperatur $\geq 0,05^{\circ} \mathrm{C} / \mathrm{m}$. Lapisan dalam yang menjadi lapisan terakhir, memiliki temperatur rendah dan relatif konstan dengan temperatur 2,63 - $13,03{ }^{\circ} \mathrm{C}$ yaitu pada kedalaman $181-2000$ meter.

Hasil untuk sebaran horizontal (melintang) temperatur disajikan pada Gambar 3. Pada gambar tersebut terlihat adanya stratifikasi temperatur yang jelas pada periode Agustus 2014 - Januari 2020. 
(a)

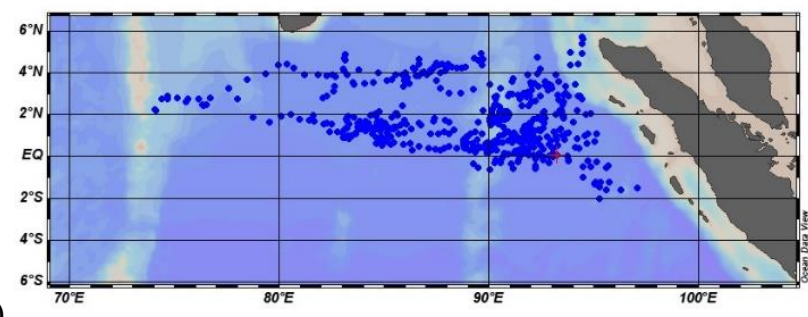

(b)

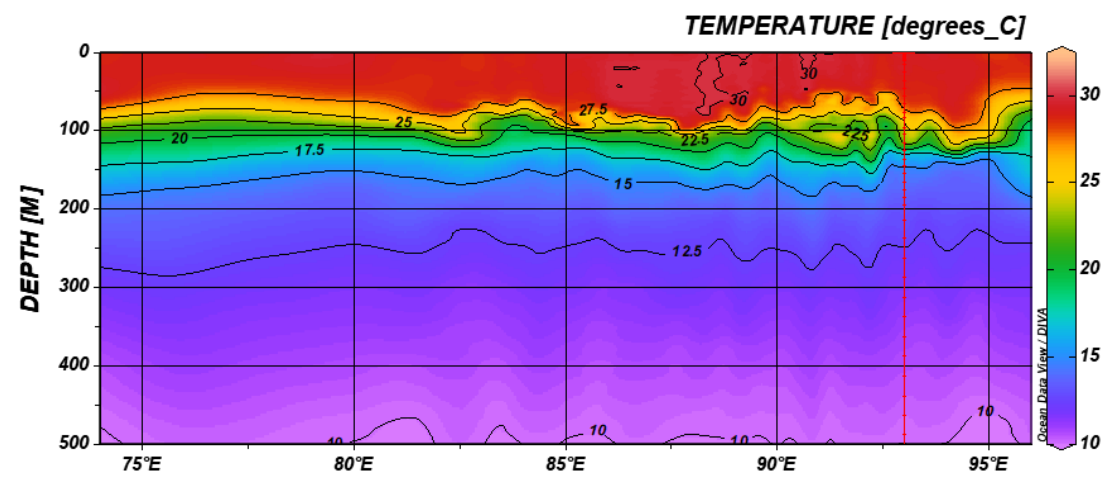

Gambar 3. (a) Peta sebaran Argo Float, (b) Sebaran Horizontal Temperatur

Sebaran secara horizontal menunjukkan fluktuasi nilai temperatur pada kedalaman 0 (permukaan) hingga kedalaman $500 \mathrm{~m}$, variasi perubahan nilai temperatur diberikan dengan kontur sesuai nilainya di setiap kedalaman serta perbedaan warna. Nilai temperatur yang tinggi akan memiliki warna yang gelap (merah) dengan rentang $31^{\circ} \mathrm{C}$ lalu dengan semakin bertambahnya kedalaman nilai temperatur akan semakin berkurang hingga $10{ }^{\circ} \mathrm{C}$ yang diberikan dengan warna semakin terang (ungu).

Sebaran horizontal temperatur secara tahunan pada Gambar 4. terdapat 7 hasil variasi sebaran. Sebaran temperatur secara tahunan dapat meninjau variasi perubahan temperatur sesuai dengan musim. Pola fluktuasi temperatur ini sebenarnya tidak sama persis setiap tahunnya.
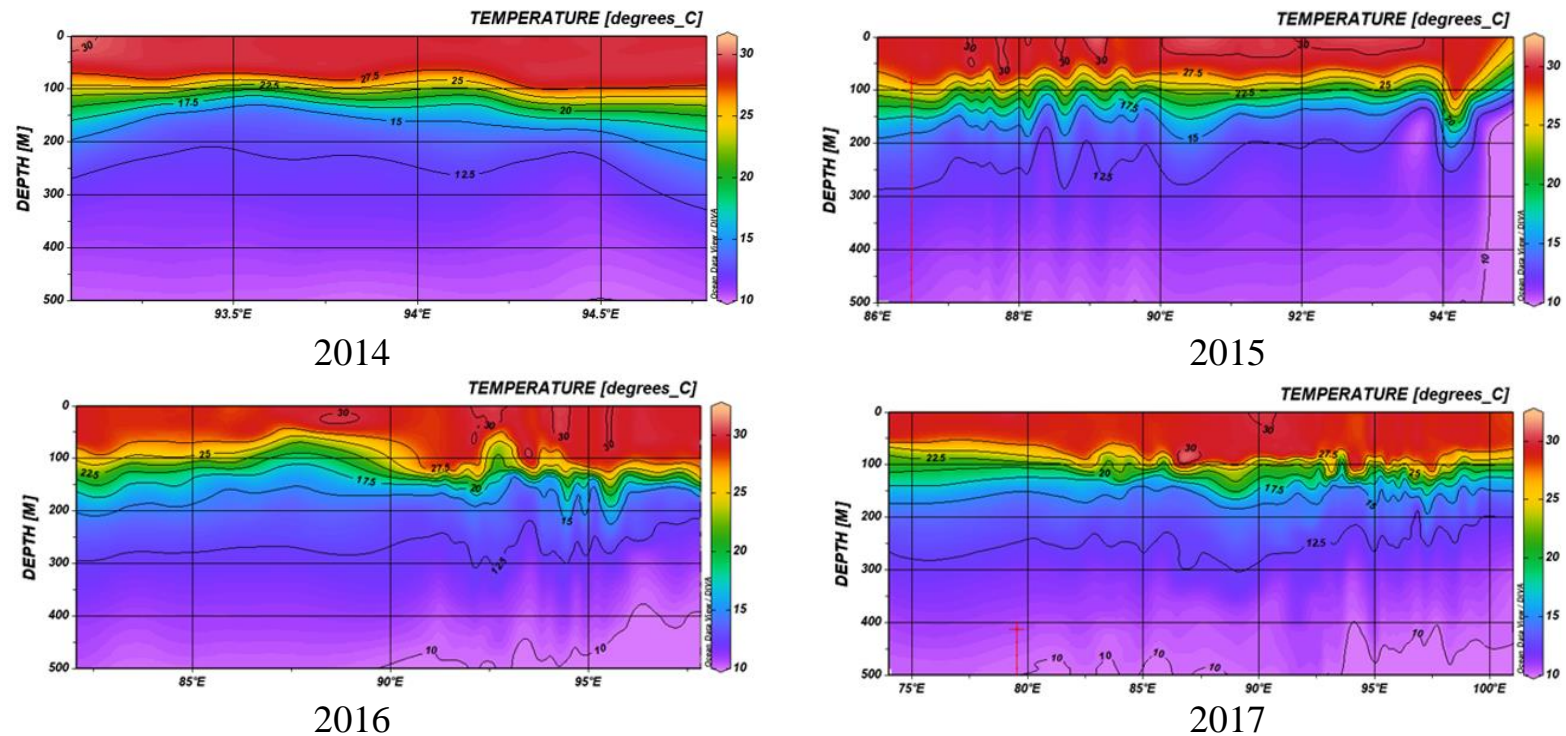

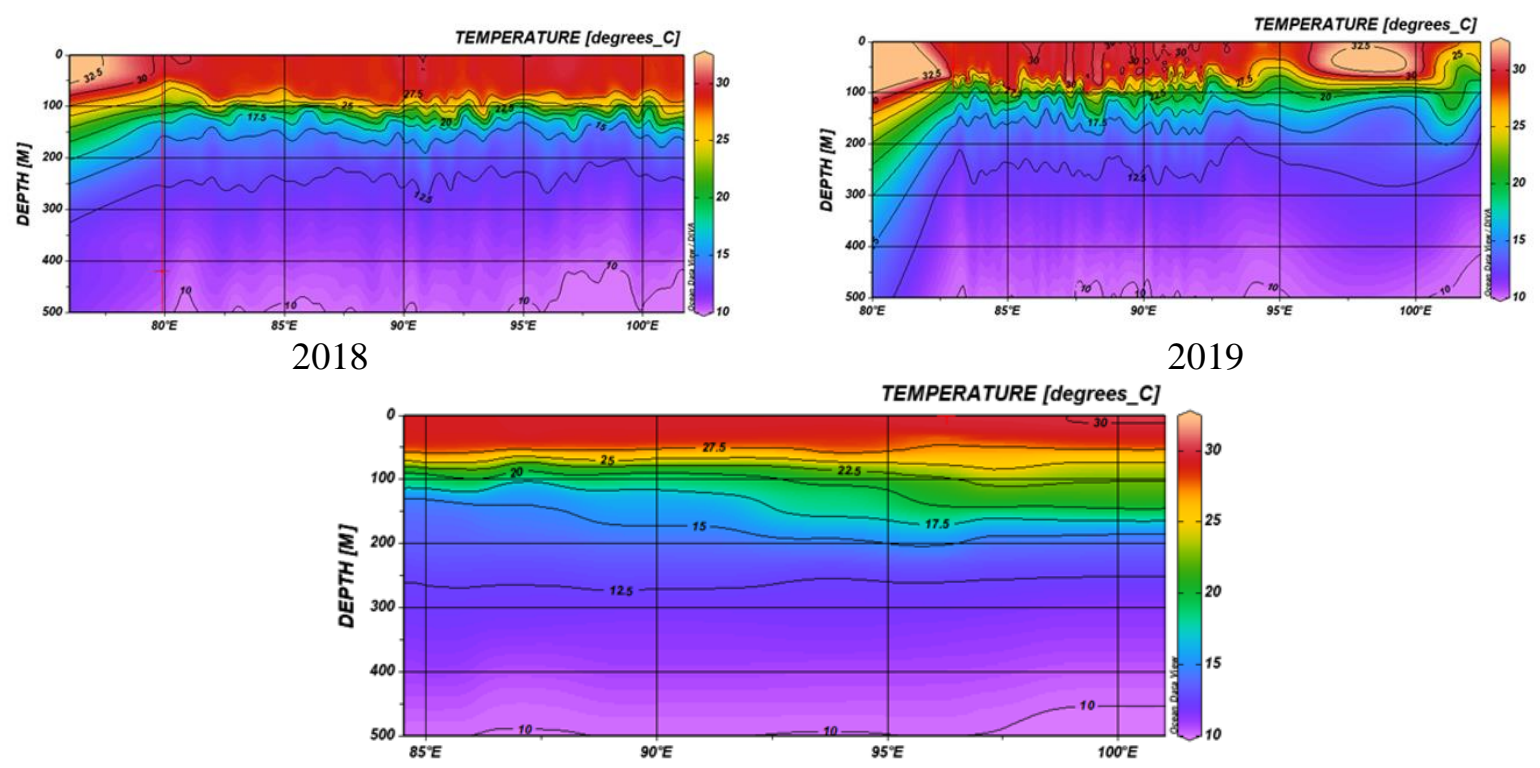

2020

Gambar 4. Sebaran Horizontal Temperatur Tahunan

Pada tahun 2015, 2019 serta Januari 2020 terlihat adanya pendangkalan lapisan mix layer, begitu juga pada tahun 2016 pendangkalan mix layer terjadi pada Musim Barat dan Peralihan I. Pada tahun 2014 yang dimulai dari bulan Agustus hingga Desember nilai temperatur ditunjukkan dengan kontur $27,5-12,5^{\circ} \mathrm{C}$. Kemudian pada tahun 2015 kontur menunjukan nilai temperatur $30-12,5^{\circ} \mathrm{C}$. Pada tahun 2016 sebaran melintang temperatur juga bervariasi, hasil kontur temperatur memiliki nilai $30-10{ }^{\circ} \mathrm{C}$. Tahun 2017 kontur menunjukkan nilai temperatur 27,5-10 ${ }^{\circ} \mathrm{C}$. Kemudian pada tahun 2018 ditunjukkan dengan kontur variasi nilai $27,5-10^{\circ} \mathrm{C}$. Lalu pada tahun 2019 nilai temperatur yang pada kontur bernilai 30-10 C, pada tahun 2015 - 2019 menggunakan data bulan Januari sampai bulan Desember. Pada tahun terakhir yaitu tahun 2020 yang hanya terdapat pada bulan Januari menunjukkan nilai temperatur dimulai $27,5-10^{\circ} \mathrm{C}$.

\section{Salinitas}

Sebaran vertikal salinitas air laut berdasarkan kedalaman di perairan Barat Sumatera pada periode Agustus 2014 - Januari 2020 disajikan pada Gambar 5. Hasil sebaran vertikal terhadap kedalaman berbentuk seperti grafik pada temperatur namun berbanding terbalik. Hasil sebaran vertikal terbagi ke dalam tiga lapisan utama, yaitu permukaan, haloklin, dan lapisan dalam seperti pada Gambar 5 .

Pada hasil tersebut menunjukkan nilai salinitas pada permukaan (0 meter) berkisar 32-35,6 psu, sehingga pada lapisan permukaan memiliki nilai salinitas yang rendah hingga yang tinggi. Sebaran vertikal salinitas menunjukkan bahwa kolom perairan terbagi menjadi tiga lapisan, yaitu lapisan mixed layer (0-24 m) dengan salinitas 32,5-33,62 psu, kemudian lapisan haloklin (25-123 m) dengan salinitas $33,7-34,63$ psu, yang terakhir lapisan dalam $(125-2000 \mathrm{~m})$ dengan salinitas 34,8 - 35,2 psu. Pada gambar 5 menunjukkan bahwa dengan bertambahnya kedalaman maka nilai salinitas akan semakin besar dan relatif konstan.

Hasil sebaran horizontal menunjukkan nilai salinitas rendah di lapisan permukaan dan mengalami fluktuasi peningkatan di lapisan haloklin, selanjutnya konsentrasi salinitas mengalami perubahan lambat dan relatif homogen di lapisan dalam seperti yang disajikan pada Gambar 6. 


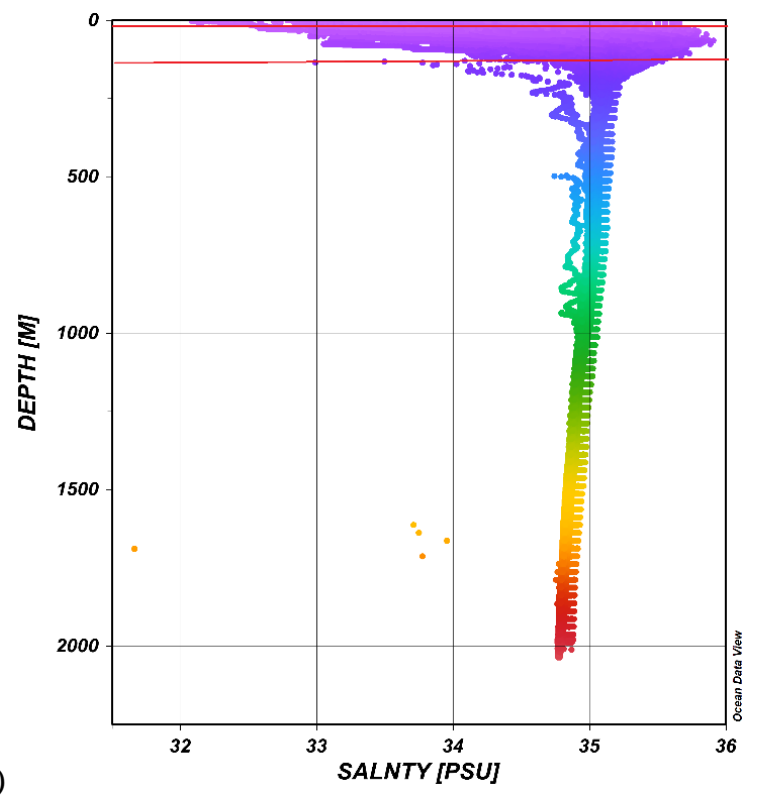

(a)

(b)

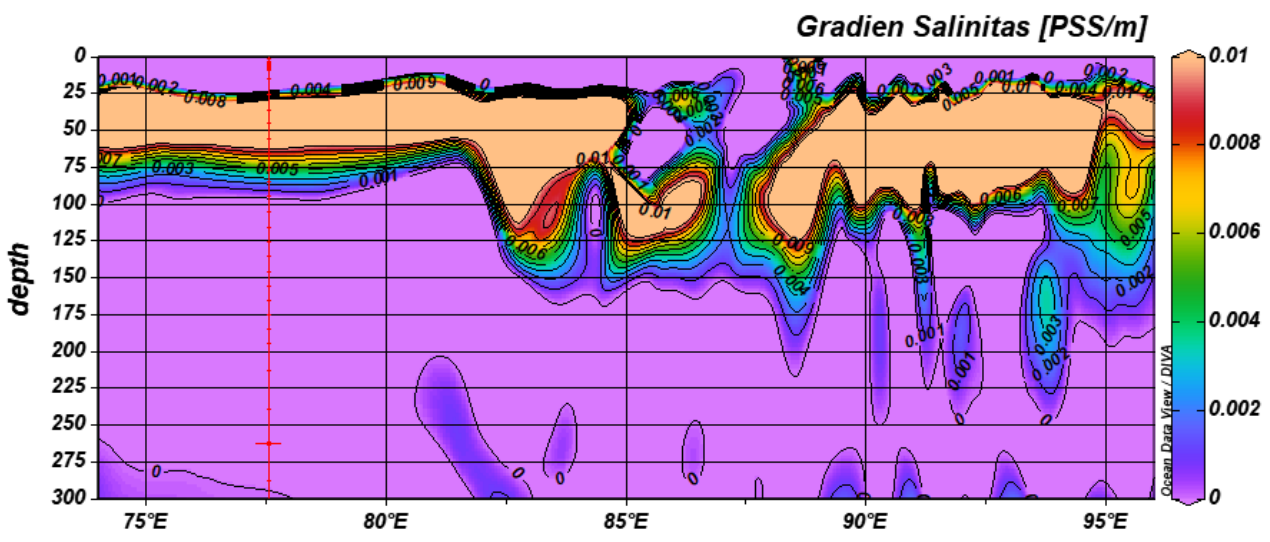

Gambar 5. (a)Sebaran Vertikal Salinitas, (b)Gradien Salinitas

(a)

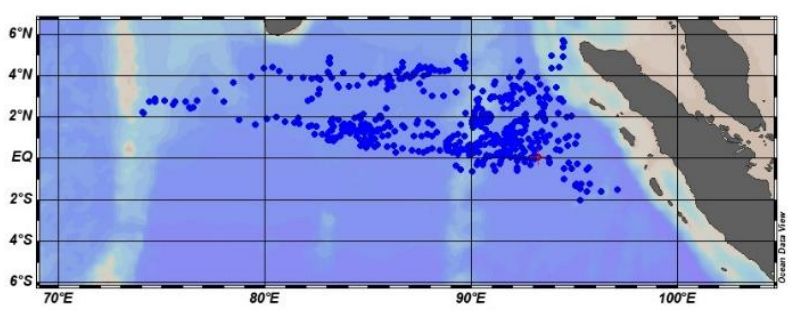

(b)

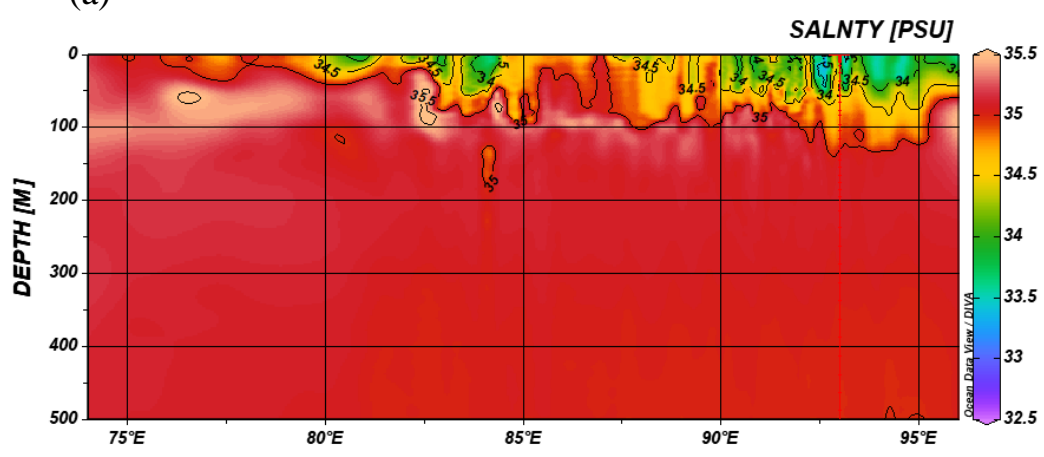

Gambar 6. (a) Peta sebaran Argo Float, (b)Sebaran Horizontal Salinitas 

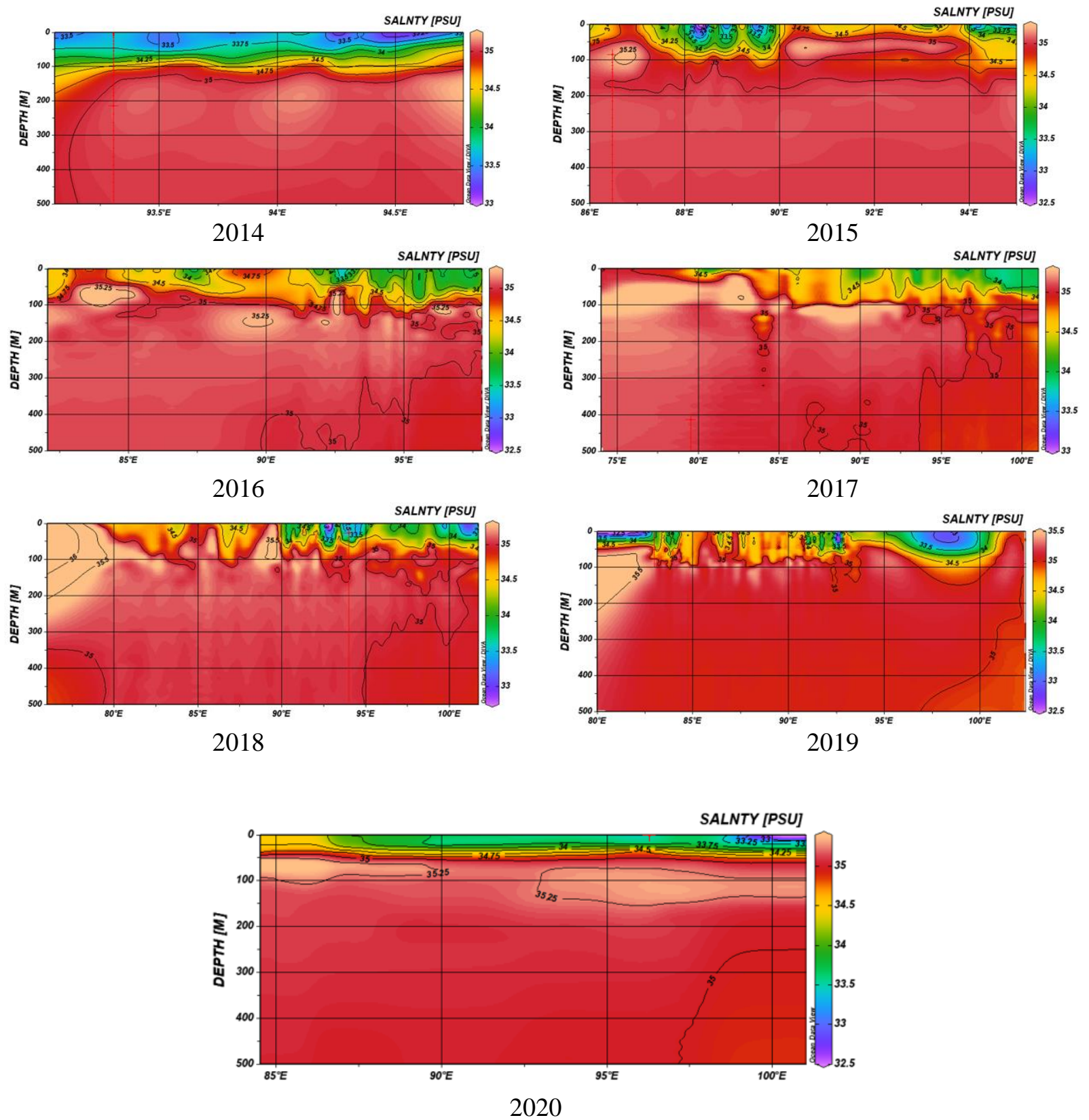

Gambar 7. Sebaran Horizontal Salinitas Tahunan.

Sebaran horizontal salinitas menunjukkan fluktuasi nilai salinitas dimana dimulai pada kedalaman 0 (permukaan) hingga kedalaman $500 \mathrm{~m}$, variasi perubahan nilai salinitas diberikan dengan perbedaan warna, yaitu nilai salinitas yang rendah akan memiliki warna yang cerah dengan rentang 32,5 psu lalu dengan semakin bertambahnya kedalaman nilai salinitas juga akan semakin bertambah besar serta homogen yaitu 35,5 psu yang diberikan dengan warna semakin gelap (merah).

Sebaran horizontal (melintang) salinitas tahunan pada perairan barat Sumatera mendapatkan 7 hasil seperti yang tersajikan pada Gambar 7 dimana dimulai dari tahun 2014-2020.

Pada tahun 2014 dimulai dari bulan Agustus - Desember memiliki nilai salinitas yang diperlihatkan oleh kontur dimulai dari 33,5-35 psu. Kemudian pada tahun berikutnya, yaitu 2015 memiliki nilai salinitas yang ditunjukkan dengan kontur bernilai 33-35 psu. Variasi sebaran secara melintang juga terdapat pada tahun 2016 dimana nilai salinitas yang ditunjukkan oleh kontur bernilai 33,75-35 psu. Tahun 2017 memiliki nilai kontur yang bervariasi juga yang bernilai 34,5-35 psu. Kemudian pada tahun 
berikutnya yaitu 2018, variasi nilai salinitas yang ditunjukkan oleh kontur bernilai 33,5-35 psu. Pada tahun berikutnya yaitu 2019 nilai salinitas yang ditunjukkan oleh kontur bernilai 33,5-35 psu. Tahun 2020 yang merupakan tahun terakhir dari hasil yang telah diolah dan berdasarkan data hanya menunjukkan bulan Januari tanggal 1-20 dimana variasi nilai salinitas yang ditunjukkan oleh kontur yaitu 33,5-33 psu.

\section{Karakteristik Massa Air}

Berdasarkan hasil dari pengolahan data salinitas terhadap potensial temperatur maka didapatlah diagram TS yang menghasilkan beberapa klasifikasi massa air yang terdapat pada Perairan Barat Sumatera yang merupakan bagian dari Samudera Hindia seperti yang ditunjukkan oleh Gambar 8.

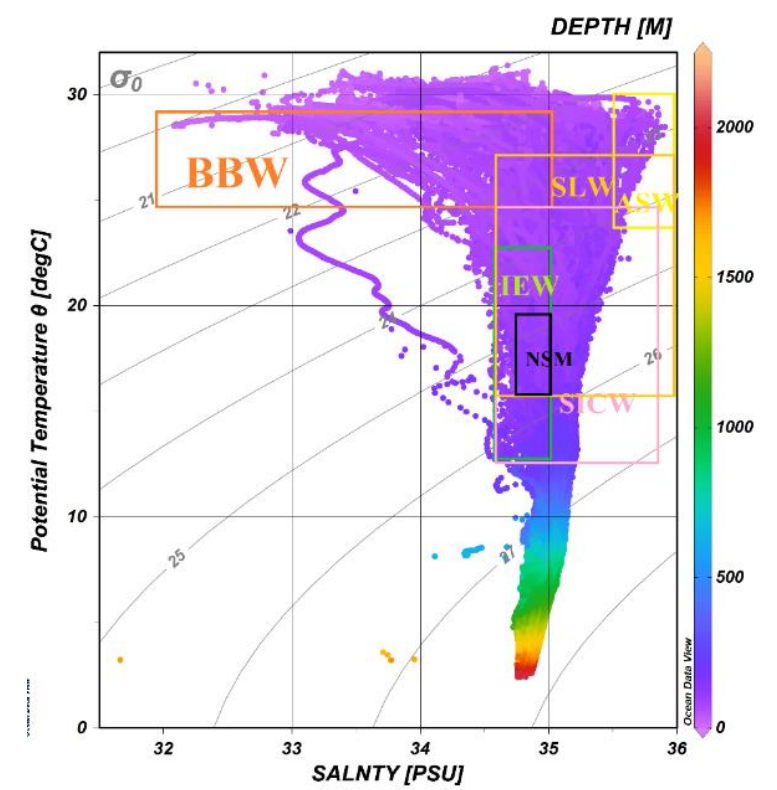

Gambar 8. Klasifikasi Massa Air Barat Sumatera

Secara kesulurahan terdapat 6 jenis massa air pada lokasi penelitian, yaitu Bengal Bay Water (BBW) dengan ciri rentang temperatur $25-29^{\circ} \mathrm{C}$ dan rentang salinitas 28-35 psu. Arabian Sea Water (ASW) dengan rentang temperatur $24-30^{\circ} \mathrm{C}$ dan rentang salinitas 35,5-36,8 psu. Indian Equatorial Water (IEW) dengan ciri temperatur $8-23{ }^{\circ} \mathrm{C}$ dan salinitas 34,6-35,8 psu, South Indian Central Water (SICW) dengan ciri temperatur 8-25 ${ }^{\circ} \mathrm{C}$ dan salinitas 34,6-35,8 psu, Subtropical Lower Water (SLW) dengan rentang temperatur $16-27{ }^{\circ} \mathrm{C}$ dan salinitas 34,6-36 psu, Northern Salinity Minimum (NSM) dengan rentang temperatur $16-19{ }^{\circ} \mathrm{C}$ dan salinitas $34,8-35$ psu. Penentuan jenis massa air memiliki parameter tersendiri berdasarkan temperatur, salinitas serta kedalamanya. Keseluruhan jenis massa air tersebut berada di Upper Waters (0-500 m).

\section{Grafik Dipole Mode terhadap SST dan Salinitas}

Grafik Dipole Mode menujukkan hasil pengolahan data nilai indeks Dipole Mode serta nilai SST pada perairan barat Sumatera. Grafik pada Gambar 9. terdapat nilai DMI yang positif serta negatif hal ini guna menunjukkan kondisi anomali temperatur pada permukaan air di perairan Samudra Hindia yang tepatnya berada di bagian barat Sumatera.

Gambar 9 menunjukkan grafik nilai anomali temperatur permukaan laut serta salinitas pada tahun 2014-2019. IOD positif memiliki nilai indeks $>0,48^{\circ} \mathrm{C}$, kemudian IOD negatif memiliki nilai indeks < $0,48{ }^{\circ} \mathrm{C}$, sedangkan indeks DMI menunjukkan bahwa IOD berada dalam posisi netral ketika berada diantara $+0,48{ }^{\circ} \mathrm{C}$ dan $-0,48{ }^{\circ} \mathrm{C}$ (Adiwira et al., 2018). Berdasarkan grafik di atas, ditemukan fenomena adanya IOD negatif terendah terjadi pada tahun 2016, berkisar bulan Juni-Oktober, dengan nilai DMI $0,73{ }^{\circ} \mathrm{C}$ hingga $-1,31^{\circ} \mathrm{C}$. Fenomena IOD positif tertinggi terjadi pada tahun 2019, pada bulan Agustus- 
November dengan nilai DMI $1,3-2,3{ }^{\circ} \mathrm{C}$. Perairan barat Sumatera memiliki nilai SST berkisar antara $28,26-30,9^{\circ} \mathrm{C}$, serta nilai salinitas permukaan berkisar $32-35,1 \mathrm{PSU}$.

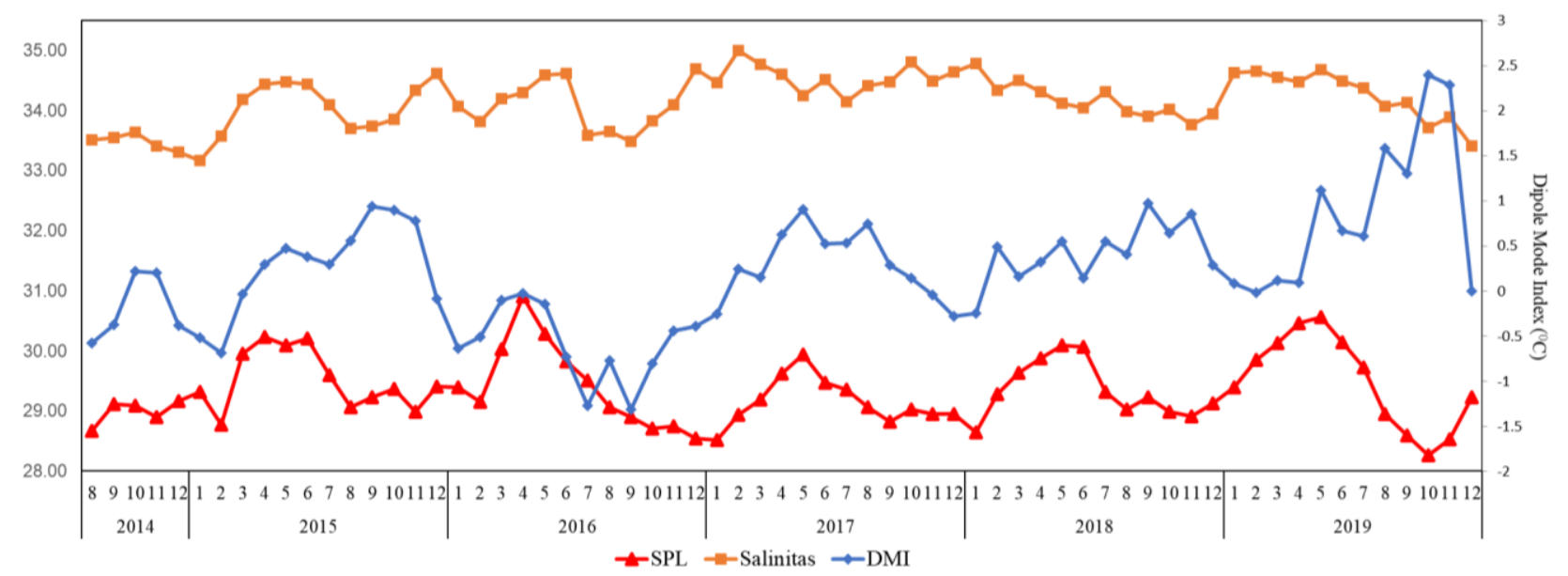

Gambar 9. Grafik Dipole Mode terhadap salinitas dan SST

(Sumber: Pengolahan Data Penelitian, 2020).

\section{KESIMPULAN}

Berdasarkan hasil yang didapat sebaran temperatur dan salinitas secara vertikal di perairan Barat Sumatera menunjukkan temperatur di lapisan Mixed Layer yaitu $27,86-31,4^{\circ} \mathrm{C}(0-25 \mathrm{~m})$, lapisan Thermochline $14,78-26,05^{\circ} \mathrm{C}(26-180 \mathrm{~m})$ dan lapisan dalam 2,63-13,03 ${ }^{\circ} \mathrm{C}(181-2000 \mathrm{~m})$. Nilai salinitas di lapisan Mixed Layer 32,5-35,62 psu (0-24 m), lapisan Halochline 33,7-34,63 psu (25-123 m) dan lapisan dalam 34,8-35,2 psu (125-2000 m). Sebaran temperatur dan salinitas secara horizontal memiliki pengaruh yang jelas sesuai musim. Temperatur permukaan tertinggi $31,39^{\circ} \mathrm{C}$ terjadi pada musim Peralihan I, sedangkan salinitas permukaan tertinggi 35,6 psu terjadi pada Peralihan II.

Massa air yang teridentifikasi pada lokasi penelitian yaitu massa air Bengal Bay Water (BBW), Subtropical Lower Water (SLW), South Indian Central Water (SICW), Indian Equatorial Water (IEW), Northern Salinity Minimum (NSM), dan Arabian Sea Water (ASW). Sedangkan hasil analisis pengaruh IOD terhadap temperatur dan salinitas menunjukkan respon terhadap aktifnya fenomena IOD, baik IOD positif yang terjadi pada tahun 2015, 2017, 2018, dan 2019, IOD netral tahun 2014, dan IOD negatif pada tahun 2016. IOD positif tertinggi (2019) mengakibatkan penurunan temperatur dan kenaikan rerata salinitas, ketika IOD negatif (2016) mengakibatkan kenaikan temperatur dan penurunan rerata salinitas.

\section{DAFTAR PUSTAKA}

Adiwira, H., Noir P.P., Syawaludin A.H., dan Mega L.S. 2018.Variabilitas Suhu Laut Pada Kejadian IOD (Indian Ocean Dipole) Di Perairan Barat Sumatera Menggunakan Data Argo Float. 7(1): $28-41$.

Emery, W.J. 2003. Ocean Circulation / Water Types and Water Masses. United States of America: Elsevier Science Ltd. 1556-1567.

JAMSTEC. 2019. www.jamstec.go.jp (19 Desember 2019).

Pranowo, W.S., Hendrajana, B., Burhanuddin, S., dan Supangat, A. 2003. Akuisisi Data Temperatur Dan Salinitas di Samudera Hindia Dengan Menggunakan Argo Floats. Badan Riset Kelautan dan Perikanan.

Saji, N.H., Goswami, B.N., Vinayachandran, P.N., and Yamagata, T. 1999. A Dipole Mode in the Tropical Indian Ocean. Nature, 401:360-363.

Sugiyono. 2009. Metode Penelitian Kuantitatif, Kualitatif dan R\&D. Alfabeta, Bandung, $380 \mathrm{hlm}$.

Wyrtki, K. 1961. Physical Oceanography of the Southeast Asian Waters. Naga Report Volume 2. Scripps Institution of Oceanography, La Jolla, California. 